\title{
DIVERSITY AND ABUNDANCE OF NEMATODES IN GUAVA (Psidium guajava L.) CULTIVATION IN LAMPUNG
}

\author{
Nabilah$^{1}$, I Gede Swibawa ${ }^{2}$, Radix Suharjo ${ }^{2}$, \& Yuyun Fitriana ${ }^{2}$ \\ ${ }^{1}$ Department of Agrotechnology, Faculty of Agriculture, Universitas Lampung, Indonesia \\ Jl. Prof. Sumantri Brojonegoro 1 Lampung 35145 \\ ${ }^{2}$ Department of Plant Protection, Faculty of Agriculture, Universitas Lampung, Indonesia \\ Jl. Prof. Sumantri Brojonegoro 1 Lampung 35145 \\ E-mail: igede.swibawa@fp.unila.ac.id
}

Manuscript received: 24 February 2021. Revision accepted: 29 June 2021.

\begin{abstract}
Diversity and abundance of nematodes in guava (Psidium guajava L.) cultivation in Lampung. Crystal guava agroecosystem is inhabited by many species of plant parasitic nematodes. However, information regarding this topic was still limited. This study aimed to understand the species dominancy of nematodes in crystal guava cultivation in Lampung. Sampling was carried out in three locations of guava crystal plantations: Lampung Timur, Lampung Tengah, and Tanggamus. The laboratory analysis was done at the Plant Pest Science Laboratory and Agricultural Biotechnology Laboratory, Universitas Lampung. The study was conducted in December 2019 - July 2020. Nematodes were identified to the level of the genus. The Prominance value (PV) was used to assess the nematodes genus dominancy. The results showed that the nematodes inhabiting the crystal guava agro-ecosystem in Lampung was both plant parasitic and free-living nematodes. The plant parasitic nematodes were identified as Meloidogyne, Aphelenchus, Hemicriconemoides, Tylenchus, Aphelenchoides, and Xiphinema, while free-living nematodes was Rhabditis, Dorylaimine, Dorylaimus, and Mononchus. The dominant plant parasitic nematode was Meloidogyne and the dominant free-living nematode was Rhabditis. The abundance of Meloidogyne $/ 300 \mathrm{~mL}$ of soil was 351.47 individuals in Lampung Timur, 124.27 individuals in Lampung Tengah, and 82.18 individuals in Tanggamus. The dominant free-living nematode in the three locations was Rhabditis.
\end{abstract}

Key words: Meloidogyne, prominance value, Rhabditis

\section{INTRODUCTION}

The diversity of nematodes in the tropics is higher than in temperate regions. Luc et al. (2005) mentioned that, the diversity of nematodes in subtropical and tropical areas was high due to higher diversity of cultivated plants compared to temperate regions. Yanto $\&$ Swibawa (2016) reported 13 genera of plant parasitic nematodes associated with banana cultivation in East Lampung. In Crystal guava cultivation, there are many species of plant parasitic nematodes that inhabit the agroecosystem. El-Borai \& Duncan (2005) reported that, more than three genera of plant parasitic nematodes inhabited the guava crop agroecosystem including, Meloidogyne, Helicotylenchus, and Tylenchorhynchus.

Plant parasitic nematodes are serious problem in the cultivation of certain types of plants due to its ability in causing serious damage to crop. These nematodes were attacking and damaging the roots so that their function as a transport of nutrients and water is not optimal. Root systems that do not function optimally could caused disorder of growth and physiological processes in plant. As a result, plants could easily wilt in dry season, stunted, chlorosis, and die (Agrios, 1996). To overcome this problem, an effective control of plant parasitic nematode population is needed.

Identification is an important step to determine the genus or species of nematodes in an agroecosystem. By knowing the nematode species, it can be easily understanding the destructive behavior and ability. Based on this knowledge, the appropriate and effective control techniques can be determined (Bridge, 1987). Information regarding the diversity and abundance of nematodes in guava cultivations in Lampung is not yet available. This information is especially important for determining the initial steps for nematode management in guava plantations. This study aimed to understand the diversity and abundance of plant parasitic nematodes as well as the dominant nematodes in guava (Psidium guajava L.) cultivation in Lampung. 


\section{MATERIALS AND METHODS}

Research Site. Soil samples were taken from the rhizosphere of guava plantations in 3 locations i.e. PT GGP Plantation Group IV (PG-IV), 5 ${ }^{\circ}{ }^{\prime} 0.8652 \mathrm{~S}$ and $105^{\circ} 41^{\prime} 33.3564$ E (Lampung Timur); PT GGP Plantation Group I (PG-I), 4 49'32.9412 S and $105^{\circ}$ 13'55.5744 E (Lampung Tengah) and Gunung Alip District, 5' 21'2.8872" S and 104' 47'12.5988" E (Tanggamus) (Figure 1). Laboratory analysis were carried out at the Plant Pest Science Laboratory and Agricultural Biotechnology Laboratory, Faculty of Agriculture, Universitas Lampung. The research was conducted in December 2019 to July 2020.

Soil Sampling and Nematode Extraction. This study was used survey methods for soil sampling. Soil samples were collected in three locations of guava crystals plantations: PT GGP PG4 (Lampung Timur), PT GGP PG 1 (Lampung Tengah), and Gunung Alip (Tanggamus). Prior to sampling, the planting plot was determined. At each sampling location, a plot of \pm 2.5 ha was determined randomly. In each plot, ten sample plants were systematically selected following the diagonal line. In each sample plant ten sub-points were assigned, five sub-points positioned on a small circle with radius
$30 \mathrm{~cm}$ from the plant and five sub-points positioned on the large circle with radius $60 \mathrm{~cm}$ from the plant (Figure 2) (Barker, 1985). At each sub-point, soil samples were taken using an auger or soil drill to a depth of about $20 \mathrm{~cm}$. Soil samples from ten sub-points were composited then $1000 \mathrm{~g}$ were taken, put in a plastic bag, and labeled for further analysis in the laboratory.

Extraction of nematodes from the soil was carried out by decantation and centrifugation methods with sugar solution (Hooper et al., 2005). Sugar solution was prepared by dissolving $500 \mathrm{~g}$ of sugar (sucrose) in water until the volume of the solution becomes $1000 \mathrm{~mL}$. As much as $300 \mathrm{~mL}$ of soil (which had previously been weighed to determine its weight) was put into a bucket, then $2000 \mathrm{~mL}$ of water was added and kneaded and left for 1 minute. The suspension was filtered using a $1 \mathrm{~mm}$ sieve and the soil was collected in a second bucket, then left for 3 minutes. After 3 minutes, the soil suspension in the second bucket was filtered again using a $53 \mu \mathrm{m}$ sieve and the soil was collected in the third bucket. The soil that attached on the sieve was collected in a beaker. Furthermore, the soil suspension in the third bucket was filtered again using a $38 \mu \mathrm{m}$ sieve. The soil suspension which attached on the sieve was added to the previous beaker. The soil suspension in the beaker glass was stirred evenly, then put into a centrifuge tube

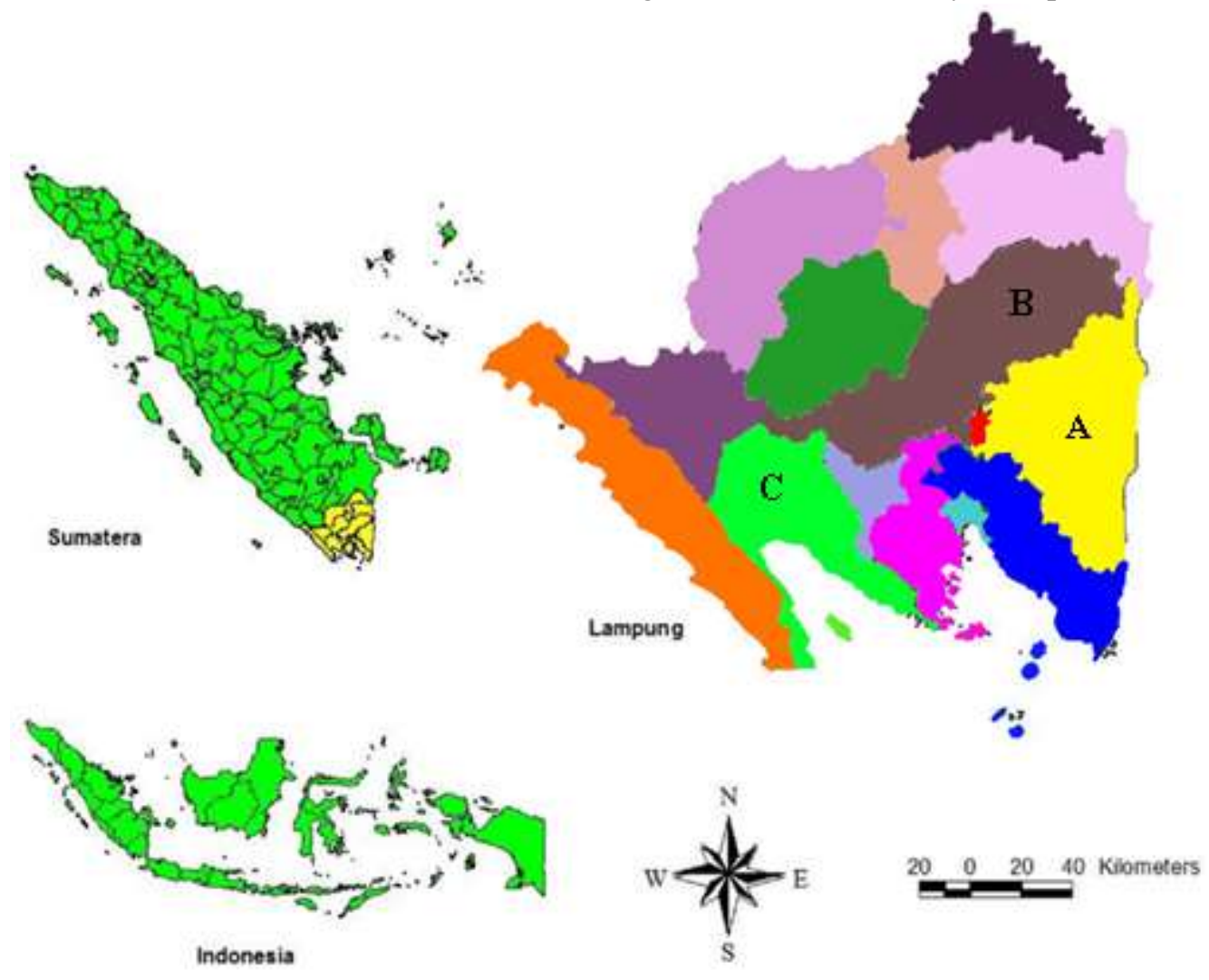

Source: Dulbari et al. (2021)

Figure 1. Sampling locations. (A) Lampung Timur; (B) Lampung Tengah; (C) Tanggamus. 
and centrifuged at $3500 \mathrm{rpm}$ for 5 minutes. After that, the supernatant was removed, the sediment was added with sugar solution then stirred until evenly distributed, then centrifuged again at $1000 \mathrm{rpm}$ for 2 minutes. Next, the supernatant which was a suspension of the nematodes in the sugar solution was rinsed under running water using a $38 \mu \mathrm{m}$ sieve to clean the sugar solution. The nematode suspension then collected in a suspension bottle and labeled.

Nematode fixation used Golden X solution which was a mixture of 90 parts of distilled water, 8 parts of formalin, and 2 parts of glycerine (Gafur \& Swibawa, 2004). Before fixation, the nematodes were killed by heating the suspension to a temperature of $60-70{ }^{\circ} \mathrm{C}$. The nematode suspension was ajust into $3 \mathrm{~mL}$, then Golden X solution was added until $10 \mathrm{~mL}$, in this condition the nematode was in 3\% formalin solution. Nematodes were counted using a hand counter under a binocular stereo microscope. The abundance of these nematodes was the number of individuals $/ 300 \mathrm{~mL}$ of soil.

Nematode identification was carried out on permanent collection slides. Permanent collection slides were made by infiltrating glycerine into the nematodes using the Seinhorst Method (Seinhorst, 1959). Seinhorst I solution was prepared from a mixture of 20 parts of $96 \%$ alcohol, 2 parts of glycerin and 78 parts of distilled water, while Seinhorst II solution was made from 95 parts of $96 \%$ alcohol and 5 parts of glycerin. A total of $3 \mathrm{~mL}$ of nematodes in a Petri dish diameter $5 \mathrm{~cm}$ were added with $7 \mathrm{~mL}$ of Seinhorst I solution so that the volume became $10 \mathrm{~mL}$, then put it in a desiccator containing $96 \%$ alcohol with a volume of $1 / 3$ part and oven at $43{ }^{\circ} \mathrm{C}$ overnight. Then the suspension was dried at $43^{\circ} \mathrm{C}$ for 4 hours until the volume was halved. Then the suspension was added with Seinhorst II solution so that it became $10 \mathrm{~mL}$ and put it back into the desiccator and oven for overnight at a temperature of $43{ }^{\circ} \mathrm{C}$, then dried again at $43^{\circ} \mathrm{C}$ for 4 hours. This process was carried out two times and ended by drying at $43{ }^{\circ} \mathrm{C}$ for 48 hours. (Hooper et al., 2005). The nematode body that been infiltrated with glycerin and was ready to be used for making permanent collection slides on glass objects and covered with a cover glass.

The identification was carried out on 100 nematodes which were taken randomly. A total of 20 individual nematodes were picked up one by one using "nematodes pick" under binocular stereo microscope, then placed on a glass preparation which was previously dropped by glycerin solution and then covered with a cover glass. The side of cover glass was coated with clear nail polish which functions as an adhesive. Nematode identification was carried out to the genus taxonomic level using a compound microscope at magnification of 100-400 times based on morphological characteristics compared with the reference books Goodey (1963), Mai \& Lyon (1975), and Smart \& Nguyen (1988). Based on the genus taxon, the nematodes were grouped into plant parasitic nematodes and free-living nematodes (Yeates et al., 1993).

The measured variables was total individuals per sample, relative population (RP), absolute population (AP), relative frequency (RF), absolute frequency (AF), and population dominance. The relative population of the nematode genus was the number of individuals of the genus per 100 nematodes identified. The absolute population of the genus was calculated by multiplying the relative population of the genus by the total nematodes per sample. Absolute frequency (AF) was

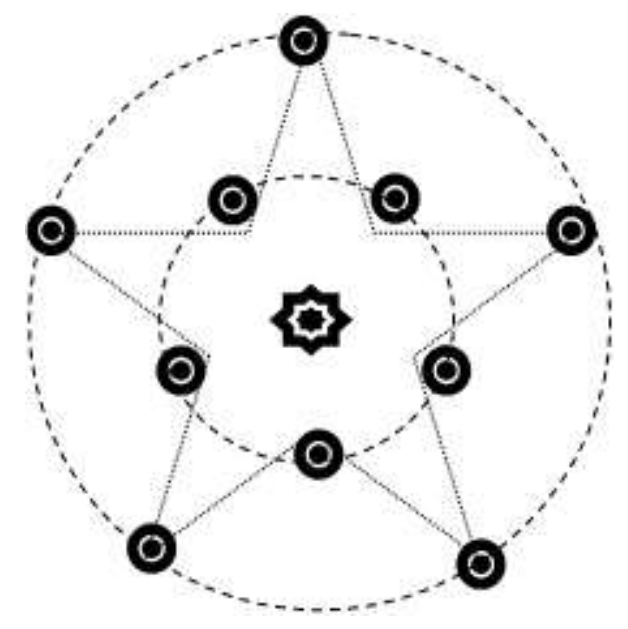

Figure 2. Soil sampling pattern at each sample plant. 
how often a species found in samples. The relative frequency of the genus was determined based on the ratio between the frequencies of each species to the total frequencies. Nematode community data were analyzed to determine the dominant nematode genus using the genus prominence value (PV) with the following formula (Beals, 1960). The AF was calculated using formula :

$\mathrm{AF}=\left(\frac{\text { Number of samples containing a genus }}{\text { number of samples collected }}\right) \times 100 \%$

The RF was analyzed using formula :

$\mathrm{RF}=\left(\frac{\text { frequency of genus }}{\text { sum of frequency of all genus }}\right) \times 100 \%$

The PV was determined :

$\mathrm{PV}=\mathrm{AP} \times \sqrt{\mathrm{AF}}$

\section{RESULTS AND DISCUSSION}

Nematode Community. A total of nine genera and one subfamily of nematodes were observed in the guava agroecosystem in Lampung (Figure 3, and Tables 1, 2, and 3). Not all genera were found in every sampling location, in PT GGP PG 4 (Lampung Timur) 6 genera and 1 subfamily were found, in PT GGP PG 1 (Lampung Tengah) there were 5 genera, and 5 genera and 1 subfamily was observed in guava plantations at Gunung Alip (Tanggamus). The nematodes found was consisted of both plant parasitic and free-living nematodes (Figure $3)$.

The plant parasitic nematodes that inhabited guava plantation in PT GGP PG 4 (Lampung Timur) were Meloidogyne, Aphelenchus, Hemicriconemoides, and Aphelenchoides, while the free-living nematodes were Rhabditis, Dorylaimus, and the subfamily Dorylaimine (Figure 3 and Table 1). The total individual of Meloidogyne was 585, the relative population was $58.50 \%$, and the absolute population was 351.47 individuals $/ 300 \mathrm{~mL}$ of soil. The relative frequency of this nematode was $33.33 \%$ and the absolute frequency was $100 \%$. The genera Aphelenchus, Hemicriconemoides, and Aphelencoides had a lower population and frequency than Meloidogyne (Table 1). The total number of Rhabditis individuals reached 383 with a relative population of $38.30 \%$, and an absolute population of 230 individuals $/ 300 \mathrm{~mL}$ of soil, an absolute frequency of 100 , and a relative frequency of $33.33 \%$. Dorylaimus, and Dorylaimine showed a lower population and frequency than Rhabditis (Table 1).

On the other hand, PT GGP PG 1 (Lampung Tengah), 5 nematode genera were found, consisting of

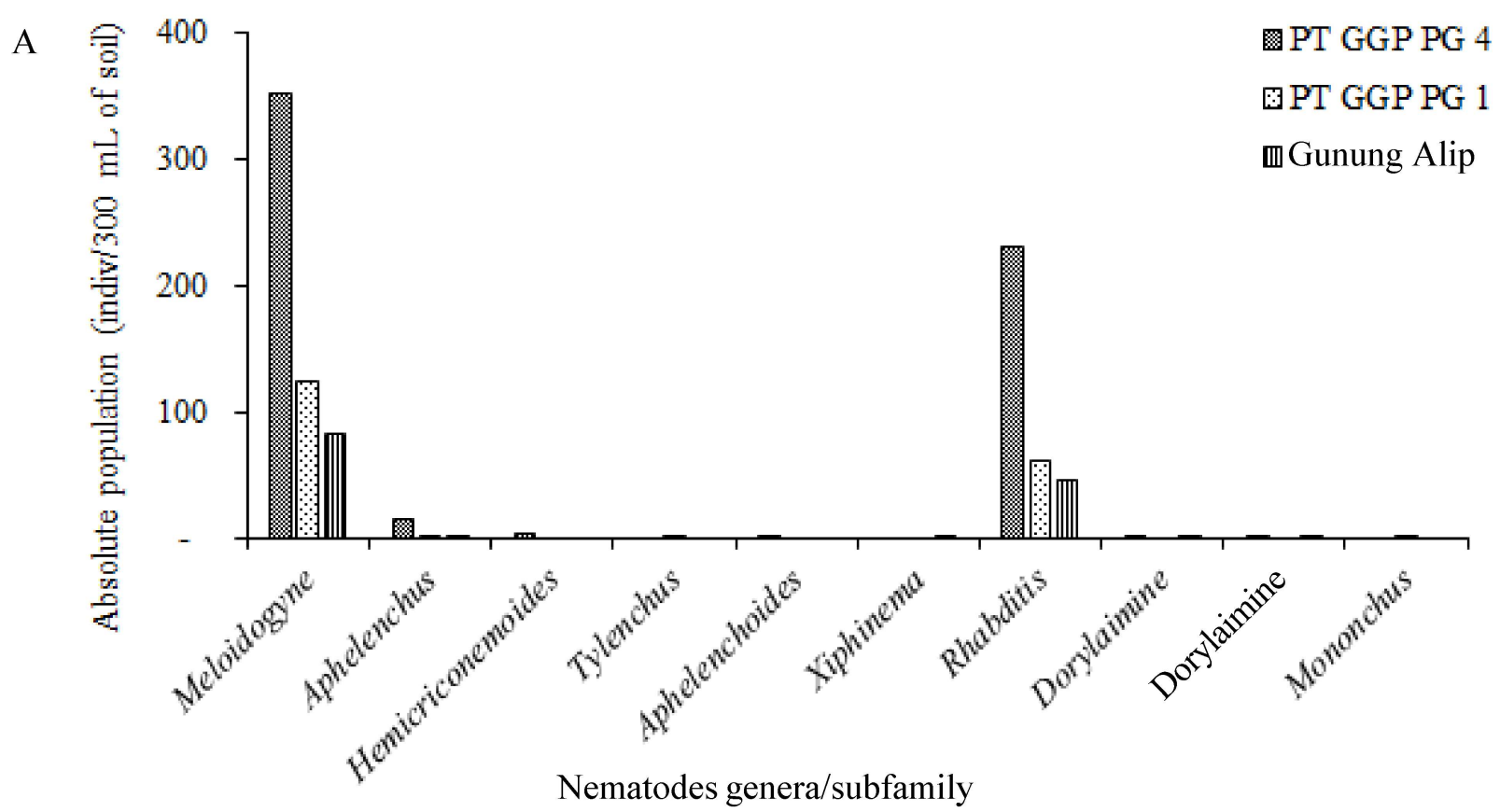

Figure 3. Absolute and relative populations of genera/subfamily of nematodes inhabited guava agroecosystem in Lampung, (A) Absolute population, (B) relative population. 
B
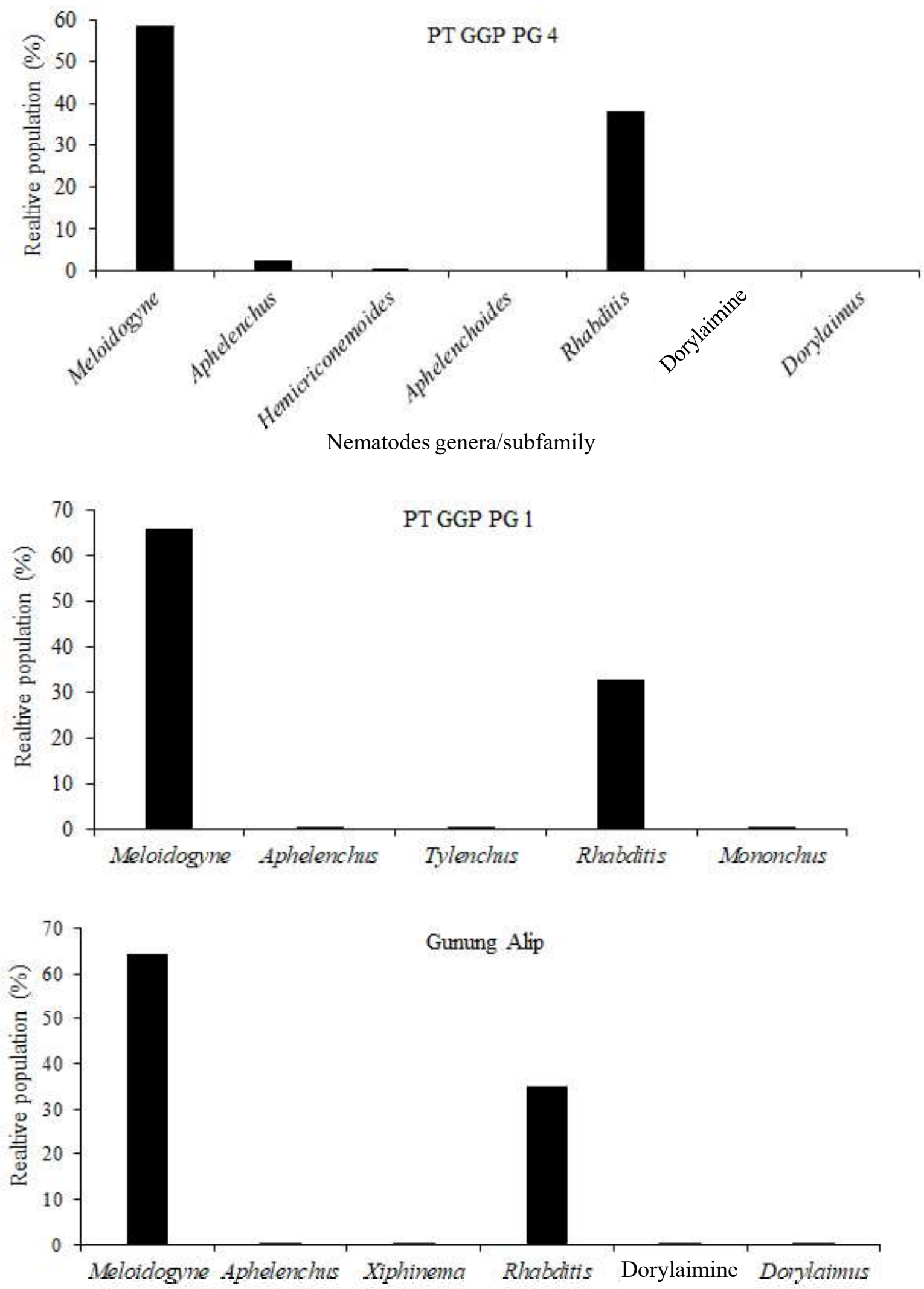

Nematodes genera/subfamily

Figure 3. Absolute and relative populations of genera/subfamily of nematodes inhabited guava agroecosystem in Lampung, (A) Absolute population, (B) relative population (continue). 
3 plant parasitic nematodes and 2 free-living nematodes (Table 2). The plant parasitic nematodes were Meloidogyne, Aphelenchus, and Tylenchus, while the free-living nematodes were Rhabditis and Mononchus. The total number of Meloidogyne individuals was 661 with a relative population of $66.10 \%$ and an absolute population of 124.27 individuals $/ 300 \mathrm{~mL}$ of soil. The relative frequency of this nematode was $34.48 \%$ and the absolute frequency was $100 \%$. The abundance and frequency of Aphelenchus and Tylenchus were lower than that of Meloidogyne (Table 2). The total number of Rhabditis individuals was 328 with a realistic population of $32.80 \%$ and an absolute population of 61.66 individuals $/ 300 \mathrm{~mL}$ of soil. The relative frequency of

Table 1. Total number of individu, population dan frequency of nematode at guava cultivations area in PT GGP PG 4 (Lampung Timur)

\begin{tabular}{lccccc}
\hline \multicolumn{1}{c}{ Genus/Subfamily } & $\begin{array}{c}\text { Total } \\
\text { individual }\end{array}$ & $\begin{array}{c}\text { Relative } \\
\text { population } \\
(\%)\end{array}$ & $\begin{array}{c}\text { Absolute } \\
\text { population/ } \\
300 \mathrm{~mL} \mathrm{soil}\end{array}$ & $\begin{array}{c}\text { Relative } \\
\text { frequency } \\
(\%)\end{array}$ & $\begin{array}{c}\text { Absolute } \\
\text { frequency } \\
(\%)\end{array}$ \\
\hline $\begin{array}{l}\text { Plant parasite } \\
\text { Meloidogyne }\end{array}$ & 585 & 58.50 & 351.47 & 33.33 & 100 \\
Aphelenchus & 23 & 2.30 & 13.82 & 16.67 & 50 \\
Hemicriconemoides & 4 & 0.40 & 2.40 & 6.67 & 20 \\
Tylenchus & 0 & 0.00 & 0.00 & 0.00 & 0 \\
Aphelenchoides & 1 & 0.10 & 0.60 & 3.33 & 10 \\
Xiphinema & 0 & 0.00 & 0.00 & 33.33 & 00 \\
Free-living & & & & 3.33 & 100 \\
Rhabditis & 383 & 38.30 & 230.11 & 3.33 & 10 \\
Dorylaimine & 1 & 0.10 & 0.60 & 0.00 & 0 \\
Dorylaimus & 3 & 0.30 & 1.80 & & \\
Mononchus & 0 & 0.00 & 0.00 & & \\
\hline
\end{tabular}

Tabel 2. Total number of individu, population dan frequency of nematode at guava cultivations area in PT GGP PG 1 (Lampung Tengah)

\begin{tabular}{lcccrr}
\hline Genus /Subfamily & $\begin{array}{c}\text { Total } \\
\text { individual }\end{array}$ & $\begin{array}{c}\text { Relative } \\
\text { population } \\
(\%)\end{array}$ & $\begin{array}{c}\text { Absolute } \\
\text { population/ } \\
300 \mathrm{~mL} \text { soil }\end{array}$ & $\begin{array}{c}\text { Relative } \\
\text { frequency } \\
(\%)\end{array}$ & $\begin{array}{c}\text { Absolute } \\
\text { frequency } \\
(\%)\end{array}$ \\
\hline Plant parasite & & & & & \\
Meloidogyne & 661 & 66.10 & 124.27 & 34.48 & 100 \\
Aphelenchus & 6 & 0.60 & 1.13 & 13.79 & 40 \\
Hemicriconemoides & 0 & 0.00 & 0.00 & 0.00 & 0 \\
Tylenchus & 3 & 0.30 & 0.56 & 10.34 & 30 \\
Aphelenchoides & 0 & 0.00 & 0.00 & 0.00 & 0 \\
Xiphinema & 0 & 0.00 & 0.00 & 0.00 & 0 \\
Free-living & & & & 34.48 & 100 \\
Rhabditis & 328 & 32.80 & 61.66 & 0.00 & 0 \\
Dorylaimine & 0 & 0.00 & 0.00 & 0.00 & 0 \\
Dorylaimus & 0 & 0.00 & 0.00 & 6.90 & 20 \\
Mononchus & 2 & 0.20 & 0.38 & & \\
\hline
\end{tabular}


this nematode was $34.48 \%$ and the absolute frequency was $100 \%$. The genus Mononchus had an abundance and lower frequency than Rhabditis.

Table 3 showed that the nematode community in the crystal guava agroecosystem in Gunung Alip (Tanggamus Regency) was consisted of 6 nematode genera; 3 genera were plant parasitic nematodes and the other 2 genera and 1 subfamily were free-living nematodes. The plant parasitic nematodes found were Meloidogyne, Aphelenchus, and Xiphinema. The freeliving nematodes that inhabited the agroecosystem were Rhabditis, Dorylaimus and Dorylaimine. The total number of Meloidogyne individuals was 641 with a relative population of $64.10 \%$, an absolute population of 82.18 individuals $/ 300 \mathrm{~mL}$ of soil. The relative frequency of this nematode was $38.46 \%$ and the absolute frequency was $100 \%$. Aphelenchus and Xiphinema were of lower abundance and frequency than Meloidogyne (Table 3). The total number of Rhabditis individuals was 350 with a relative population of $35.00 \%$ and an absolute population of 44.87 individuals $/ 300 \mathrm{~mL}$ of soil. The relative frequency of this nematode was $33.33 \%$ and the absolute frequency was $100 \%$. Dorylaimine and Dorylaimus showed an abundance and lower frequency than Rhabditis.

Nematode Dominance. Nematotode dominance was measured using prominence value (PV). Meloidogyne, a plant parasitic nematode was dominant in the crystal guava agroecosystem in three planting locations (Table
4). The PV of Meloidogyne in the planting location at PT GGP PG4 (Lampung Timur) was 3514.68, at the location of PT GGP PG 1 (Lampung Tengah) was 1242.68, and at Gunung Alip (Tanggamus) was 821.76. Another plant parasitic nematode PV in nematode communities on guava cultivations area at the three sampling sites was much smaller than the Meloidogyne.

Rhabditis was the dominant free-living nematodes in the nematode community that inhabited the guava agroecosystem in the three planting locations. At PT GGP PG 4 (Lampung Timur), the PV of Rhabditis was 2301.6, at PT GGP PG 1 (Lampung Tengah) the PV was 616.64 and at Gunung Alip (Tanggamus) was 448.70. Other free-living nematodes were found to have lower PV than Rhabditis (Table 4).

Nine genera and 1 subfamily of nematodes consisting of 6 plant parasitic nematodes and 4 freeliving nematodes were found in guava cultivation agroecosystem (Tables 1, 2, and 3). Twelve genera of nematodes consisting of 9 plant parasitic nematodes and 3 free-living nematodes had been reported on guava plantations in West Bengal, India (Khan et al., 2007). Pradhan et al. (2020) reported that 13 genera of nematodes consisting of ten plant parasitic nematodes and three free-living nematodes were associated with guava cultivation in Bhubaneshwar, India. Several genera were found in all three sampling locations, while other genera were only found at one location where crystal guava was grown. The plant parasitic nematodes

Tabel 3. Total number of individu, population dan frequency of nematode at guava cultivations area in Gunung Alip (Tanggamus)

\begin{tabular}{lccccc}
\hline \multicolumn{1}{c}{ Genus/Subfamily } & $\begin{array}{c}\text { Total } \\
\text { individual }\end{array}$ & $\begin{array}{c}\text { Relative } \\
\text { population } \\
(\%)\end{array}$ & $\begin{array}{c}\text { Absolute } \\
\text { population/ } \\
300 \mathrm{~mL} \text { soil }\end{array}$ & $\begin{array}{c}\text { Relative } \\
\text { frequency } \\
(\%)\end{array}$ & $\begin{array}{c}\text { Absolute } \\
\text { frequency } \\
(\%)\end{array}$ \\
\hline Plant parasite & & & & & \\
Meloidogyne & 641 & 64.10 & 82.18 & 38.46 & 100 \\
Aphelenchus & 6 & 0.60 & 0.77 & 0.00 & 30 \\
Hemicriconemoides & 0 & 0.00 & 0.00 & 0.00 & 0 \\
Tylenchus & 0 & 0.00 & 0.00 & 0.00 & 0 \\
Aphelenchoides & 0 & 0.00 & 0.00 & 3.33 & 10 \\
Xiphinema & 1 & 0.10 & 0.13 & & 100 \\
Free-living & & & 44.87 & 3.33 & 10 \\
Rhabditis & 1 & 35.00 & 0.13 & 3.33 & 10 \\
Dorylaimine & 1 & 0.10 & 0.13 & 0.00 & 0 \\
Dorylaimus & 0 & 0.10 & 0.00 & & 0 \\
Mononchus & 0.00 & & & \\
\hline
\end{tabular}


that inhabited all three locations were Meloidogyne and Aphelenchus, while free-living nematodes that inhibited all three locations were Rhabditis. Other nematodes were only found at one or two planting sites of crystal guava.

Based on the PV, Meloidogyne was the dominant plant parasitic nematode and Rhabditis was the dominant free-living nematode at the three crystal guava planting sites in Lampung. These two genera of nematodes had the highest PV in the nematode communities of plant parasites and free-living nematodes, respectively (Table 4). This finding was different with the similar report by Pradhan et al. (2020) which reported that, in fruit crops including guava in India the plant parasitic nematode that had the highest PV was Rotylenchulus reniformis while the free-living nematode that had highest PV was Dorylamid.

Meloidogyne was dominant in the nematode community in crystal guava plantations in Lampung, indicating that this nematode was important in guava cultivation. This could occur because these nematodes were widespread, polyphagous (Muin, 2008), and had a large host range (Shurtleff \& Averre, 2000). According to Luc et al. (2005) plant parasitic nematodes were considered important, because they were able to cause severe losses. Thus, Meloidogyne can become an important pest in crystal guava cultivation in Lampung.
This finding was consistent with the report of Swibawa et al. (2018) which mentioned that, nematodes that attacked crystal guava plantations in East Lampung were Meloidogyne incognita and M. javanica. Some researchers also reported that Meloidogyne was an important pest in guava cultivation (Milan, 2007; Rahman et al., 2008; Razak \& Lim, 1987).

Other parasitic nematodes in guava plantations in Lampung were Aphelenchus, Hemicriconemoides, Tylenchus, Aphelenchoides, and Xiphinema. The presence of some of these plant parasitic nematodes was not dominant and the population was low. Of all the parasitic nematodes found in guava plantations in Lampung, the Aphelenchus and Xiphinema, were also reported to be associated with guava crops in India (Khan et al., 2007).

Rhabditis was a dominant free-living nematode in guava plantations in Lampung. Based on the function in the ecosystem, this nematode feed organic matter degrading bacteria (Yeates et al., 1993). The presence of these nematodes which were dominant and abundant in guava plantations could be an indication that the agroecosystem conditions were rich in organic matter which became a substrate for bacteria. Luckyana et al. (2020) stated that, free-living nematode communities, which were dominated by bacterial-feeders

Tabel 4. The prominence value (PV) of nematode genus or famili inhibiting guava cultivation agroecosystem in Lampung

\begin{tabular}{lccc}
\hline Genus/Subfamily & \multicolumn{3}{c}{ Location } \\
\cline { 2 - 4 } & $\begin{array}{c}\text { PT GGP PG 4 } \\
\text { (Lampung Timur) }\end{array}$ & $\begin{array}{c}\text { PT GGP PG 1 } \\
\text { (Lampung Tengah) }\end{array}$ & $\begin{array}{c}\text { Gunung Alip } \\
\text { (Tanggamus) }\end{array}$ \\
\hline Plant parasite & 3514.68 & 1242.68 & 821.76 \\
Meloidogyne & 97.71 & 7.13 & 4.21 \\
Aphelenchus & 10.75 & 0.00 & 0.00 \\
Hemicriconemoides & 0.00 & 3.09 & 0.00 \\
Tylenchus & 1.90 & 0.00 & 0.00 \\
Aphelenchoides & 0.00 & 0.00 & 0.41 \\
Xiphinema & & & \\
Free living & 2301.06 & 616.64 & 448.70 \\
Rhabditis & 1.90 & 0.00 & 0.41 \\
Dorylaimine & 5.70 & 0.00 & 0.41 \\
Dorylaimus & 0.00 & 1.68 & 0.00 \\
Mononchus & 7 & 5 & 6 \\
\hline Total genus & & & \\
\hline
\end{tabular}


nematodes, increasing the rate of organic matter decomposition the soil.

The abundance and diversity of nematodes on guava plantation in Lampung might affected by the climate conditions and soil types. PT GGP on PG 4 in Lampung Timur and PG-1 in Lampung Tengah had the same soil type and climate condition. The soil type in those plantations was Ultisol with sandy-clay texture and the climate condition as follow: rainfall was 2,971.56 $\mathrm{mm} /$ year and the temperature maximum $31.8^{\circ} \mathrm{C}$, minimum $23.6^{\circ} \mathrm{C}$, with average $27.3^{\circ} \mathrm{C}$ and the Relative Hummidity (RH) was 89.05\% (Nugroho, 2021; personal communication). The soil type of guava plantation in Gunung Alip (Tanggamus) was Inseptisol (Hafif et al., 2017), with climate condition as follow: rainfall was $1800-2000 \mathrm{~mm} /$ year, temperature was $26-30{ }^{\circ} \mathrm{C}$, average $28{ }^{\circ} \mathrm{C}$, and $\mathrm{RH} 80-88 \%$, average $84 \%$ (https:/ /sippa.ciptakarya.pu.go.id).

\section{CONCLUSION}

Based on the results, it could be concluded that the plant parasitic nematodes found in guava plantations in Lampung were Meloidogyne, Aphelenchus, Hemicriconemoides, Tylenchus, Aphelenchoides, and Xiphinema. The free-living nematodes were Rhabditis, Dorylaimus, Dorylaimine and Mononchus. Meloidogyne was a dominant and important plant parasitic nematode in Crystal guava cultivation in Lampung with $\mathrm{PV}=3514.68$ and an abundance of 351.47 individuals $/ 300 \mathrm{~mL}$ of soil in PT GGP PG 4 (Lampung Timur), $\mathrm{PV}=1242.68$ and an abundance of 124.27 individuals/300 $\mathrm{mL}$ of soil in PT GGF PG 1 (Lampung Tengah), and PV $=821.76$ and an abundance of 82.18 individuals $/ 300 \mathrm{~mL}$ of soil in Gunung Alip (Tanggamus). The dominant free-living nematode in the three locations was Rhabditis.

\section{ACKNOWLEDGMENTS}

We would like to acknowledge the management of PT GGP PG 4 Lampung Timur and PT GGF PG 1 Lampung Tengah as well as guava farmers at Gunung Alip, Tanggamus who had helped and facilitated many research activities. We also do thanks to the Faculty of Agriculture, Universitas Lampung for permitting us using research facilities during this study.

\section{REFERENCES}

Agrios GN. 1996. Plant Pathology. Academic Press, California.
Bridge J. 1987. Control strategies in subsistence agriculture. In: Brown RH \& Kerry BR (Eds.). Principles and Practice of Nematode Control in Crops. pp. 289-420. Academic Press. Australia.

Barker KR. 1985. Sampling nematode communities. In: Barker KR, Carter CC, \& Sasser JN (Eds.). An Advanced Treatise on Meloidogyne Vol. II: Methodology. pp. 2-17. North Carolina State University Graphics, Raleigh.

Beals E. 1960. Forest bird communities in the Apostle Islands of Wisconsin. Wilson Bull. 72(2): 156181.

Dulbari, Santosa E, Koesmaryono Y, Sulistyono E, Wahyudi A, Agusta H, \& Guntoro D. 2021. Local adaptation to extreme weather and it's implication on sustainable rice production in Lampung, Indonesia. AGRIVITA. 43(1): 125-136.

El-Borai FE \& Duncan LW. 2005. Nematode parasities of subtropica and tropical fruit crops. In: Luc M, Sikora RA, \& Bridge J (Eds.). Plant Parasitic Nematodes in Subtropical and Tropical Agriculture. $2^{\text {nd }}$ edition. pp. 467-492. CABI Publishing. Walingford UK.

Gafur A \& Swibawa IG. 2004. Methods in nematodes and soil microbe research for belowground biodiversity assessment. In: Susilo FX, Gafur A, Utomo M, Evizal R, Murwani S, \& Swibawa IG (Eds.). Conservation and Sustainable Management of Below-Ground Biodiversity in Indonesia. pp. 117-123. Unversitas Lampung. Lampung.

Goodey JB. 1963. Soil and Freshwater Nematodes. Mathuen and Co Ltd. London.

Hooper DJ, Hallman J, \& Subottin SA. 2005. Methods for extraction, processing and detection of plant and soil nematodes. In: Luc M, Sikora RA, \& Bridge J (Eds.). Plant Parasitic Nematodes in Subtropical and Tropical Agriculture $2^{\text {nd }}$ Ed. pp. 53-86. CABI Publishing. Walingford UK.

Hafif B, Mawardi R, \& Utomo JS. 2017. Analisis karakteristik lahan dan mutu biji pala (Myristica fragrans Houtt) daerah Lampung. Jurnal Littri. 23(2): 63-71.

Khan MR, Hassan A, Ghosh B, Das B, Ghosh S, \& Ray SK. 2007. Diversity and community analysis 
of soil nematodes associated with guava from West Bengal, India. Acta Hortic. 735: 483-487.

Luc M, Bridge J, \& Sikora RA. 2005. Reflections on nematology in subtropical and tropical agriculture. In: Luc M, Sikora RA, \& Bridge J (Eds.). Plant Parasitic Nematodes in Subtropical and Tropical Agriculture $2^{\text {nd }}$ Ed. pp. 1-10. CABI Publishing. Walingford UK.

Luckyana DR, Puspitasari IGAA, \& Maharning HR. 2020. Bacterial $(9 \mathrm{~A} 2 \mathrm{H})$ enhancement alters the nematode community structure and decomposition pathway of amended nutrient-limited soil. Biodiversitas. 21(10): 4813-4820.

Mai WF \& Lyon HH. 1975. Pictorial Key to Genera of Plant-Parasitic Nematodes. Cornell University, London.

Milan AR. 2007. Breeding of Psidium species for root knot nematode resistance in Malaysia. Acta Hortic. 735: 61-69.

Muin A. 2008. Nematologi Tumbuhan; Biologi, Ekologi, dan Pengendalian. IPB Press, Bogor.

Pradhan P, Patra MK, \& Sahoo NK. 2020. Association of nematodes with fruit crops in Bhubaneswar, India. Int. J. Curr. Microbiol. App. Sci. 9(5): 1918-1923.

Rahman MA, Najah Y, \& Umikalsum MB. 2008. Preliminary screening for Meloidogyne incognita resistance in selected Psidium species. J. Trop. Agric. Food Sci. 36(2): 1-8.

Razak AL \& Lim TK. 1987. Occurence of the rootknot nematode Meloidogyne incognita on guava in Malaysia. Pertanika. 10(3): 265-270.
Seinhorst JW. 1959. A rapid method for the transfer of nematodes from fixative to anhydrous glycerin. Nematologica. 4(1): 67-69.

Shurtleff MC \& Averre III CW. 2000. Diagnosing Plant Diseases Caused by Nematodes. American Phytopathological Society. St Paul, Minnesota.

Smart GC \& Nguyen KB. 1988. Illustrated Key for the Identification of Common Nematodes in Florida. University of Florida, Florida.

Swibawa IG, Saputri ER, Yulianti E, Fitriana Y, \& Solikhin. 2018. Nematoda puru akar dan cendawan parasitnya pada pertanaman jambu biji di Lampung. In: Khaeruni A, Tufaila M, Muhidin, Sutariati GAK, Rahayu M, Bande LOS, Gusnawaty HS, Hidayat SH, Baharuddin, Rosmana A, Kuwinati T, Budi IS, Lisnawita, \& Sriwati R (Eds.). Prosiding Seminar Nasional dan Kongres Perhimpunan Fitopatologi Indonesia. pp. 442-450. Universitas Halu Oleo, Kendari.

Yanto \& Swibawa IG. 2016. Status fitonematoda pada tiga kisaran umur lahan pertanaman pisang Cavendish di Way Kambas, Lampung. JFI. 12(3): 83-88.

Yeates GW, Bongers T, De Goede RGM, Freckman DW, \& Georgieva SS. 1993. Feeding habits in soil nematode families and genera-an outline for soil ecologists. J. Nematol. 25(3): 315-331. 